\author{
Oláh ANDrÁs PÁL \\ olahandraspal@gmail.com \\ történész (Szeged)
}

\title{
Az OVERLORD hadmüvelet, azaz az 1944. évi nyugat-európai partraszállás számára nyújtandó légi támogatás a Földközi-tengeri térségböl
}

\author{
(forrásközlés)
}

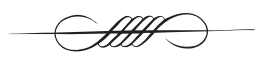

\section{- Operation OVERLORD - The Possibilities of Air Support by Mediterranean Allied Air Force (source publication) -}

Force

Keywords air support, operation Overlord, Mediterranean Theater, Mediterranean Allied Air

DOI 10.14232/belv.2015.4.9 http://dx.doi.org/10.14232/belv.2015.4.9

Cikkre való hivatkozás / How to cite this article: Oláh András Pál (2015): Az OVERLORD hadművelet, azaz az 1944. évi nyugat-európai partraszállás számára nyújtandó légi támogatás a Földközi-tengeri térségből. Forrásközlés. Belvedere Meridionale 27. évf. 4. sz. 123-128. pp

ISSN 1419-0222 (print) ISSN 2064-5929 (online, pdf)

(Creative Commons) Nevezd meg! - Így add tovább! 4.0 (CC BY-SA 4.0)

(Creative Commons) Attribution-ShareAlike 4.0 International (CC BY-SA 4.0)

Az OVERLORD hadmüvelet ${ }^{1}$ előkészületei kapcsán meggondolásra került a mediterrán térségből indítható támogató és elterelő célú hadműveletek kérdése. A legnagyobb szárazföldi elterelő hadműveletnek magát az olaszországi hadszíntéren folyó harcokat lehetett tekinteni, ahol 1944. január 12-től nagyszabású támadás volt kibontakozóban a Gusztáv-vonal ellen. Ez az Anzio és Monte Cassino térségében lezajlott véres csatákban teljesedett ki, végül Róma 1944. június 4-i elfoglalását eredményezte.

1 A szövetségesek nyugat-európai inváziója mint ismeretes, végül 1944. június 6-án kezdődött meg.
Ezzel egyidőben a szövetséges hírszerzés elemzés, valamint megfontolás tárgyává tette a Földközi-tengeri Szövetséges Légierő (Mediterranean Allied Air Force - MAAF) ${ }^{2}$ által nyújtható légi támogatás lehetőségeit is. Ugyan összefüggéseiben korábban is sejthető volt, az alább közölt dokumentum bizonyítékul szolgál arra, hogy a légiúton történő

2 Az MAAF felállítására 1943. december 10-én került sor. Alárendeltségébe került a térségben tevékenykedő összes szövetséges légiegység. Állománytáblázatáhozlásd: Craven, Wesley Frank-CATE, James LeA (1983): The Army Air Forces in World War II. Vol. Two. Washington D.C., Office of Air Force History. 840. A továbbiakban, követve a forrás nyelvezetét, igyekszem az eredeti rövidítéseket használni. 
támogatási lehetőségek az alábbiak lehettek:

1. A folyamatban lévő hadmüveletek, főként a POINTBLANK ${ }^{3}$, folytatása és befejezése.

2. A balkáni szállítási útvonalak rombolása.

3. Az OVERLORD hadművelet által megkívánt elterelő támadások.

4. A német kézben lévő, az MAAF hatósugarába került olajipari objektumok lerombolása.

Ezek mindegyike megvalósult utóbb, több-kevesebb sikerrel, annak ellenére, hogy a dokumentum keletkezésekor mindezek csak fikcióként és lehetőségként merültek fel. Jelenleg a nyugati szövetséges és a szovjet kapcsolatok, valamint a közöttük zajló információk áramlásának mértéke csak találgatásokra ad lehetőséget, de a szövetséges katonai hírszerzést dicséri egyrészt az, hogy a várható szovjet csapatmozgások irányait is meglehetősen pontosan felmérte. Másrészt azt is, hogy mindezen hadműveletek (főként az „olajháború” néven elhíresült), túlmutatva az OVERLORD hadmüvelet támogatásán, hosszútávon valóban Németország és balkáni szövetségeseinek bukását eredményezték.

\section{$\begin{array}{llllll}\mathbf{T} & \mathbf{I} & \mathbf{T} & \mathrm{K} & \mathrm{O} & \mathrm{S}\end{array}$}

\section{OVERLORD - A légi támogatás lehetőségei az MAAF-nál ${ }^{4}$}

1. Jelen dolgozat célja az, hogy vizsgálat alá vegye a közvetlen, illetve közvetett módon

\footnotetext{
3 A magyar nyelvű források helytelenül a szövetségesek egyesített bombázóoffenzívájával (CBO-Combined Bomber Offensive) azonosítják, valójában ennek a hadműveletnek az első fázisát takarta. A hadművelet célja a német vadászvédelem megtörése, valamint az európai légtér fölötti teljes uralom megszerzése volt. A hadmüvelet 1943. június 14-től vette kezdetét (Pointblank directive).

4 Eredeti címe: OVERLORD - The Possibilities of Air Support by M.A.A.F., Air Force Historical Research Agency (AFHRA)
}

az OVERLORD támogatásának, valamint a németek végső legyőzésének kapcsán a németek ellen kialakult helyzetet, valamint az MAAF együttműködésének lehetőségeit, és a támadható célpontokat.

\section{A JELENLEGI HELYZET}

Azellenséget azalábbi nagystratégiailépések fenyegetik, melyek közül bármely, vagy bármelyek kombinációja megvalósulhat:
a. Támadás az OVERLORD területén.
b. Támadás a keleti fronton.

1. Orosz támadás Jassyból Barladon át a Galatz ${ }^{5}$-Focsani vonal ellen, majd tovább a bukaresti alföldre.

2. Konyev hatalmas seregének támadása ${ }^{6}$ a Lwow-Przemysl-Tatár hágó tengelyen át a magyar Alföldig ${ }^{7}$, vagy egy északi és nyugati irányú támadás a Kárpátok körül Lengyelországba, a Krakkó-Breslau ${ }^{8}$ tengelyen. ${ }^{9}$

c. A mediterrán térségből és az Egyesült Királyságból történő légitámadások folytatása a létfontosságú ipari célpontok ellen, amely hadmüveleteknek a sikere bizonyosan kihat majd az ellenség

5 Az eredeti szövegben Jassy, a mai Iasi, Barlad, a mai Birlad, Galatz, a mai Galati helységneveket takarja. A feltételezett támadás iránya északról dél felé.

6 Konyev marsall alárendeltségébe az 1. Ukrán Front egységei tartoztak. Ezek Lengyelország déli részén, Szilézián keresztül törtek át az Elba felé.

7 A feltételezett támadás iránya délnyugat.

8 Az eredeti szövegben Krakow, Breslau a mai Wroclaw. A feltételezett támadás iránya északnyugat.

91944 nyarán a keleti fronton a hatalmas méretű BAGRATYION hadműveletet Belorussziából a német Közép hadseregcsoport ellen 1944. június 23-án indították meg az 1. balti, valamint a szovjet 1., 2 . és 3. belorusz front csapatai. Nyugat-Ukrajna felöl 1944. július 13-án kapcsolódott be a harcokba az 1., 2. 3. és 4. Ukrán Front, a német Észak-Ukrajna, valamint a Dél-Ukrajna hadseregcsoport ellen. Ezekben a hadműveletekben a szovjet csapatok a német Közép hadseregcsoportot felörölték, az Észak-Ukrajna, valamint a Dél-Ukrajna hadseregcsoportot pedig egészen a Kárpátokig visszanyomták. 
fronton való helytállására.

d. Politikailag a Balkán, fóként Románia és Bulgária legyőzéséből következne a Reich déli szárnyának kiszolgáltatottsága. A német háborús gazdaság elvesztené alapvető utánpótlását, amelyet jelenleg a Balkán és Törökország biztosít számára, végül a Fekete-tenger megnyílna a szövetséges hajózás előtt.

\section{FELTÉTELEZÉSEINK}

A fentiek kapcsán a következőket tételezzük fel:

a. Az OVERLORD július 1-je előtt megindul.

b. AzOVERLORDdalegyidőben, illetveegy olyanidőpontban, amelyaz OVERLORD időszakába esik, Oroszország támadást indít a Tatár-hágó térségében, és/vagy a Galatz-Focsani vonal ellen.

c. A 8. $\mathrm{AAF}^{10}$ jórészt taktikai célokkal lesz elfoglalva az OVERLORD keretein belül, de a 15. AAF hatósugarán kívül eső fontos célokat is le tudja majd fedni.

\section{AZ MAAF STRATÉGIAI KÉPESSÉGEI}

Az MAAF hatókörébe jelenleg a következő stratégiai müveletek esnek:

a. A meglévő direktíva keretein belül a POINTBLANK folytatása és további kiaknázása, úgymint légi parkok ${ }^{11}$, repülőtereken tartózkodó repülőgépek, javítómühelyek elleni támadások a Foggia körüli 650 mérföld $^{12}$ sugarú körben.

b. A balkáni közlekedési vonalak elleni támadások, melyek célja:

10 Army Air Force (légi hadsereg); A 8. AAF Angliában, a 15. AAF Olaszországban állomásozott.

11 Az eredeti szövegben „air parks”. Itt valószínüleg a repülőgépgyárak, összeszereldék raktárairól, vagy lerakatairól van szó.

12 Pontosan $1040 \mathrm{~km}$, ez volt az MAAF egységeinek az általános hatótávolsága.
1. Egy orosz áttörés elősegítése a bukaresti alföldre a Galatz-Focsani vonalon keresztül.

2. Németország balkáni csatlósai legyőzésének siettetése.

c. Az OVERLORD által megkívánt elterelő támadások.

d. Támadások a német kézen lévő olajipari létesítmények és raktárkészletek ellen.

A fenti lehetőségeket folytatólag áttekintjük.

\section{A POINTBLANK FOLYTATÁSA ÉS TOVÁBBI KIAKNÁZÁSA STB.}

A 8. és a 15. AAF POINTBLANK hadművelete elsősorban a német repülőgépipar és az ahhoz kapcsolódó iparágak ellen irányult. Ezeknek a támadásoknak az volt a fó célja, hogy szétmorzsolják az ellenség légierejét, ezáltal szabadabban mozoghassanak a szövetséges bombázók, és gyengébb ellenállásba ütközzön az OVERLORD. Hogy ez a hadművelet milyen mértékben volt sikeres, azt az új gyártású ME109-esek utóbbi 2 hónapban észlelt számbeli csökkenése jelzi. Tudomásunk szerint áprilisban ennek a géptípusnak mindössze 150 példánya készült $\mathrm{el}^{13}$, és ha a további bombázás már nem is akadályozza a gyártást, akkor sem várható, hogy a típusból ennél nagyobb számú repülőgépet gyártanak le májusban. Ezen repülőgéptípus gyártási potenciáljának nagyobb része az MAAF hatókörébe esik. A kétmotoros vadászgépekből a területen $\mathrm{kb} .50$ darabot gyártanak havonta, és ez valószínüleg májusban is így marad. A gyártás elleni közvetlen támadássorozat mellett az MAAF az ellenség vadászerejét is erőteljesen morzsolja.

Az MAAF területén a golyóscsapágy gyártás mértéke a hat hónappal ezelöttinek kevesebb, mint a harmadára esett vissza.

Elöfordulhat, hogy mindezen termékeknek a gyártását nem lehet már további bombázással jobban akadályozni. Ennek az az oka, hogy az ellenség képes tartani egy gyártási minimumot a gyáregységek szétszórásával.

\footnotetext{
13 Az információ alátámasztására nincs adatom.
} 
Azáltal, hogy sikerült lecsökkentenünk az új termékek termelését, a késztermékek és a javítóegységek a következő két hónapban nagyobb jelentőséggel bírnak majd, amikor is várhatóan beindul az OVERLORD. Valószínűleg a németek hatalmas légi veszteségeket szenvednek, amely még fontosabbá teszi a repülőgép utánpótlást, föként a vadászgépekét. Egy rövid ideig a repülőgép utánpótlást föként a légi parkok és a javítómühelyek fogják biztosítani, ezért eddig a POINTBLANK és más célpontok tekintetében a MAAF azzal segített leginkább az OVERLORDnak, hogy végleg lerombolta a már majdnem teljesen szétrombolt célpontokat, valamint fokozta a támadásokat a légi parkok, a kész repülőgépek és a szerelőcsarnokok ellen.

A 15. AAF ezeket mind le tudja folytatni, mégis lehetséges, hogy ez a program nem hagy elegendő alternatívát az időjárási zónák miatt a légierő lehető legteljesebb kihasználására. Ugyanakkor a bevetések levezénylése, és a kész gépek elleni támadások folyamatos elkötelezettséget jelentenek, tehát további POINTBLANK célokat kell felderíteni, hogy a legjobban ki lehessen használni az erőinket. Ebből kifolyólag elképzelhető, hogy szükséges lesz az új kategóriájú célpontok felvételének mérlegelésére a POINTBLAK keretein belül.

\section{A BALKÁNI KÖZLEKEDÉSI VONALAK ELLENI TÁMADÁSOK}

A dél-orosz fronton történő sikeres német ellenállás, a Románia és Bulgária feletti politikai ellenőrzés fenntartása, valamint a Balkán ásványkincseinek kiaknázása nagymértékben függ attól, hogy a sérülékeny vasúti közlekedést fenn tudják-e tartani Jugoszláviában, továbbá a Duna és a Kárpátok között. Az MAAF képes lehet arra, hogy a németeket a Balkánról való kivonulásra sarkallja úgy, hogy:

a) Taktikai segítséget nyújt a várható orosz támadáshoz azáltal, hogyösszezavarja az ellenség közlekedési vonalait, és a keleti front déli szektorából való evakuációját. b) Az ellenség Dél-Balkánon állomásozó egységeinek utánpótlási útvonalait támadja, segítséget nyújtva a partizánoknak.

c) Azellenség balkánigazdasági erőforrásait csökkenti az olaj, króm és réz szállítási útvonalainak támadásával.

Egy ilyen (német) visszavonulásnak a következő előnyei lennének:

a) Németország végső legyőzéséhez nagymértékben hozzájárulna, valamint megnyitná a közvetlen tengeri és szárazföldi útvonalakat Oroszország felé.

b) Az észak-balkáni, beljebb fekvő repülöterekről is indulhatnának a bombázók és a vadászkísérők.

c) Azalapvetőnyersanyagokutánpótlásának megszünése komoly csapás lenne a német hadiipar számára.

\section{ELTERELŐ TÁMADÁSOK AZ OVERLORD ÉRDEKÉBEN}

Ezek a támadások az alábbi két csoportba oszthatóak: azok, amelyek speciálisan a fö célkitűzésről akarják elterelni az ellenség figyelmét, illetve azok a támadások, melyek az MAAF fő célkitűzéséről terelik el a figyelmet, és csak korlátozott céljuk van.

Valószínü, hogy meg kell felelni az OVERLORD terv bizonyos követelményeinek. Ezek tulajdonképpen a mediterrán térségben állomásozó repülő haderők által végrehajtott olyan bombatámadások lennének, amelyek elterelnék az ellenség figyelmét, és a kevésbé fontos területeken a földhöz szegeznék az ellenség haderejét. Végül pedig, ha felgyorsulnak az események, például Olaszországban, specifikus támadásokra lesz szükség, amelyek a vasúton történő szárazföldi csapatmozgatásokat akadályoznák.

$\mathrm{Az}$ ilyen elterelő műveletek, bár már a végrehajtásuk kapcsán is fontosak, az MAAF részéről csak csekély erőfeszítést igényelnének, és a feladatok többségét közép-és könnyübombázókkal is végre lehetne hajtani. 


\section{AZ OLAJKÉSZLETEK ELLENI TÁMADÁSOK}

A 15. AAF hatókörébe tartozó olajipari célpontok közül aránylag kevés megtámadása is már jelentős eredménnyel járna.

A célcsoportok a következők:

a) 7 csoportja a Ploesti környékén lévő olajfinomítóknak. ${ }^{14} \mathrm{Ez}$ a csoport jelenleg 8.865.000 tonnát termel évente, azaz a német olajfinomítók össztermelésének $60 \%$ át, továbbá az összes német (szintetikus és nyersolaj termékek) gyártási kapacitás 1/3-át.

b) 12 finomító Közép-Európában (Magyarország, Ausztria, Csehszlovákia), amelyek összes kapacitása kb. 2 millió tonna évente. Ez Németország összes finomító kapacitásának 11\%-a és teljes készletének 13\%-a (szintetikus és nyersolaj).

c) 4 szintetikus olajgyár - Brüx, Blechammer ${ }^{15}$ észak és dél, illetve Deschowitz amelyek mindegyike jelenleg bővítés alattáll. ${ }^{16}$ Ez a négy gyár összesen $\mathrm{kb} 1.580 .000$ tonnát termel évente a jelenlegi színvonalon. Ez a teljes német szintetikus olajgyártási kapacitásnak hozzávetőlegesen 1/4-ét teszi ki, valamint a kombinált nyers- és szintetikus olajtermelés több mint 10\%-át.

Tehát a 15. AAF hatókörébe került Ploesti, a 12 további finomító és a 4 szintetikus gyár elleni sikeres támadások megfosztanák Németországot azoktól a létesítményeitől, amelyeknek az összes nyers- és szintetikus olaj készletének több, mint felét köszönheti. A 8 .

14 A mai Ploiesti. Az itt található finomítók közül a legfontosabbak az Orion (Phoenix), Colombia, Dacia, Astra Romana, Lumina, Concordia Noria, Fratia, Standard és a Campina voltak. Attacks On NonActive Oil Targets, AFHRA A6539; Oil Industry Targets For The 15th Air Force, AFHRA

15 Az eredeti szövegben helytelenül Bleckhammer.

16 A Blechammer körüli gyárak az IG Farben, a Deschowitz (Odertal) melletti a Schaffgetsch Benzin, a Brüx melletti üzem a Brabag cég tulajdonában voltak. Weekly Survey of Axis Europe Oil Production No. 25, 29 December 1944, AFHRA
AAF által 10 további szintetikus olajgyár ${ }^{17}$ ellen indított sikeres kiegészító támadás a 15 . AAF célpontjaival együtt Németország szintetikus olajkészlete háromnegyedének elpusztulását jelentené, ami a teljes német olajkészlet több, mint háromnegyed része.

Egy idő múlva a kiesett, finomított olajkészlet egy részét pótolni tudják a nyugat-európai finomítókba küldött nyersolaj feldolgozásával, amelyek jelenleg vagy egyáltalán nem, vagy nagymértékben kapacitásukon alul müködnek, mindazonáltal ez nem jelentene számottevőbb termelési hányadot, ráadásul ezeket a finomítókat bármikor légitámadás érheti.

Annak érdekében, hogy döntő taktikai eredményeket érjünk el, ezeknek a támadásoknakérinteniükkella tartálytelepeket és raktárkészleteket ${ }^{18}$ is. Ezen felhalmozott tartalékok mennyiségét és helyszínét érintő adatok még nem teljeskörüek, azonban eleget tudunk ahhoz, hogy megállapítsuk, hogy az olaj nagy részét valószínüleg maguk a finomítók környékén tárolják, valamint a fö vasúti és kikötői központokban, mint például Giurgiu, Ploesti és Constanta. Lehetséges, hogy ezeket a készleteket is érinteni tudjuk az olaj és vasúti célpontok támadása során úgy, hogy az olajat és olajipari termékeket szállító vezetékeket, valamint az áttöltő állomásokat is bombázzuk.

\section{9. ÖSSZEFOGLALÁS}

Ennek az esszének a célja mindössze az, hogy annak a lehetőségeit vizsgálja, hogyan segíthené az MAAF az OVERLORDot, valamint hogy mivel járulhatna hozzá közvetlenül Németország legyőzéséhez. A feltételezések az időtényezőn és az

17 A legfontosabb telepek Pölitz, Gelsenberg, Scholven, Welheim, Lievin, Bethune, Leuna, Böhlen, Magdeburg, Zeitz, Lutzkendorf, A. G. Für Kraft és Wesseling voltak. Enemy Oil Committee - Western Axis SubCommittee: Estimated Production of Synthetic Oils in Axis Europe - 1943., AFHRA

18 Az eredeti szövegben: tank farms, storage depots 
események lehetséges irányán alapulnak, emiattaproblémákköreleszükülhetegyre, amely a légierő főleg taktikai természetü problémája, és emiatt nem tekinthető az MAAF erők teljes kidolgozott tervének. Ez nyilvánvaló, ha a 15. AAF lehetséges célpont követelményeit vizsgáljuk. Lehetséges, hogy a jelenlegi program és a javaslatok nem biztosítanak elegendö féle célpontot a különféle területeken bevethető erők teljes kihasználásához, amelyek időről időre az időjárás által is akadályoztatva vannak. $\mathrm{Az}$ ebben a beszámolóban szereplő referenciák alapján az MAAF leghasznosabb hozzájárulása az OVERLORDhoz tehát a következő:

a) Azoknak a célpontoknak a lerombolása, amelyek repülőgépgyártással kapcsolatosak, valamint a támadások fokozása a légi parkokban és javítómühelyekben található késztermékek, valamint a repülőtereken lévő repülőgépek ellen. Ezek a támadások közvetlen segítséget jelentenének minden fronton, mivel pontosan a nagyszabású hadműveletek közben szakítanák meg a repülőgép utánpótlást, továbbá a német légierö ${ }^{19}$ vadászgép erejének további gyöngítése a MAAF bombázók hatékonyabb és kevésbé költséges kihasználásához vezetne.

b) A Galatz térségén át történő, dél felé irányuló orosz támadás esetén fontos segítséget nyújtanának a korlátozott német szállítási útvonalak elleni támadások. A célpontok átgondolt kiválasztásával kétszeres hatást érhetnénk el: összezavarhatnánk a katonai utánpótlást, valamint a Balkánból Németországba áramló nyersanyagellátást.

c) Az MAAF képes elterelő támadásokat indítani, amelyek az ellenséget félrevezetnék, vagy a létfontosságú

19 Az eredeti szövegben GAF, azaz German Air Force. területekre történő specifikus mozgásokat akadályoznák meg. Az ilyen támadások bizonyos részét, főként DélFranciaországban, könnyü- és közepes bombázók is végrehajthatnák.

d) A német olajlétesítmények elleni támadások hosszabb távú hadműveletet jelentenek, és ami az MAAF-ot illeti, ezt 6-8 hétnél kevesebb idő alatt nem tudná kivitelezni. Ez a támadás tehát nem lenne valójában közvetlen taktikai hatással a hadmüveletekre az elkövetkezendö 2 hónapban, kivéve az orosz frontot, azonban az ilyen célpontok kitöltenék nehézbombázóink programját, ugyanakkor komoly csapást jelentenének a folyamatos szövetséges offenzívákkal szembeni német ellenállás számára.

1944. április $29 .^{20}$

WRL/5

Földközi-tengeri Szövetséges Légierő főhadiszállása, Hírszerzési részleg
20 Az eredeti szövegben elmosódott, így lehet 28-a is, de valószínübb a 29-e. 